\title{
Penentuan Dividend Payout Ratio: Bukti Empiris pada Perusahaan LQ 45 di Indonesia
}

\author{
Sriyono ${ }^{1}$, Andriana $^{2}$ \\ ${ }^{1}$ Universitas Muhammadiyah Sidoarjo \\ sriyono@umsida.ac.id \\ ${ }^{2}$ Universitas Muhammadiyah Sidoarjo \\ risetya_putri@yahoo.com
}

\begin{abstract}
The determination of the dividend payout ratio is a crucial decision in a company, on the company's side must add satau capital for operations while on the other hand the company must retain investors. This research aims to find out what variables affect the stability of the Dividend Payout Ratio on the company's LQ45 listed in Indonesia stock exchange period 2012-2016. Sampling technique used is the method of purposive sampling, data analysis using Technical data analysis panel. The results of this research found a connection between the variable profitability, Leverage, size of company, Earning per share against the Dividend Payout Ratio. Conclusion of this research is the variable size of the influential company profitability and significantly to the stability of the Dividend Payout Ratio, while the Leverage Earning per share is not significant effect against the Dividend Payout Ratio.
\end{abstract}

Keywords: determination of the dividend payout ratio, $L Q 45$

\begin{abstract}
ABSTRAK
Penentuan besarnya dividend payout ratio merupakan keputusan yang krusial dalam suatu perusahaan, pada satu sisi perusahaan harus menambah modal untuk operasional sementara di sisi lain perusahaan harusmempertahankaninvestornya. Penelitian ini bertujuan untuk mengetahuivariableapasaja yang mempengaruhistabilitasDividend Payout Ratio pada perusahaan LQ45 yang Terdaftar di Bursa Efek Indonesia periode 2012-2016. Teknik pengambilan sampel yang digunakan adalah metode purposive sampling, Teknis analisis data menggunakan analisis data panel. Hasil penelitian ini ditemukanadanyahubunganantara variabel profitabilitas, Leverage, Ukuran perusahaan, Earning per share terhadap Dividend Payout Ratio.Kesimpulandaripenelitianiniadalahvariabel profitabilitasdanukuranperusahaan berpengaruh signifikan terhadapstabilitasDividend Payout Ratio, sementara itu LeverageEarning per share tidak berpengaruh signifikan terhadap Dividend Payout Ratio.
\end{abstract}

Kata kunci : Penentuan dividend payout ratio, $L Q 45$

\section{PENDAHULUAN}

Besarnya dividend yang akan diberikan perusahaan kepada insvestor merupakan hal yang sangat penting, karena ini akan menyangkut tentang berapa besar laba yang akan ditahan untuk menambah modal perusahaan, sehingga peran seorang manajer keuangan harus semakin luas dan mampu bekerja lebih keras untuk mempertahankan stabilitas perusahaan (Agustina, 2016).
Setiap perusahaan memiliki tujuan utama yaitu memperoleh laba untuk memenuhi kesejahterakan para pemegang saham yang ada dalam perusahaan tersebut.(Duha, 2009). Penetapkan dividen merupakan salah satu fungsi dari manajer keuangan, kebijakan dividen yang optimal mampu menciptakan keseimbangan diantara dividen saat ini dan pertumbuhan di masa yang akan dating (Kania, SL and Bacon, FW, 2005) 
sehingga dapat memaksimumkan harga saham. Perusahaan yang memiliki nilai saham yang tinggi memiliki prospek di masa depan (Sumanti, 2015).

Menurut Okpara, G. C. (2010)Dividend Payout Ratio merupakan presentase dari laba yang akan dibagikan sebagi dividen dan disebut sebagai rasio kebijakan dividen. Salah satu fungsi dari manajer keuangan adalah menetapkan deviden, kebijakan dividen sendiri menyangkut tentang masalah penggunaan laba yang menjadi hak para pemegang saham. Pada dasarnya, laba tersebut bisa dibagi sebagai dividen atau ditahan untuk diinvestasikan kembali (Husnan dan Pudjiastuti, 2006).

Pengukuran laba, perusahaan mengukur dengan profitabilitas sebagai rasio yang digunakan perusahaan untuk mengukur kemampuan perusahaan menghasilkan laba (Eriotis, N 2005).Bagi pimpinan perusahaan, profitabilitas dapat dijadikan sebagai tolak ukur untuk mengetahui keberhasilan dari perusahaan yang dipimpinya, sedangkan bagi investor profitabilitas dapat dijadikan sinyal dalam melakukan investasi pada suatu perusahaan (Sriyono dan Rukhul Abadi. 2017). Kemampuan perusahan untuk membayar dividen merupakan fungsi dari keuntungan. Dengan demikian profitabilitas sangat diperlukan perusahaan jika hendak membayarkan dividen, karena profitabilitas mempengaruhi jumlah dividen yang akan dibagikan oleh perusahaan(Parua, A., \& Gupta, A., 2009)

Selain masalah dalam pembagian deviden, pemilik perusahaan juga mempunyai kepentingan dengan tingkat leverage, tetapi untuk alasan yang berbeda. Seringkali pemilik menginginkan perusahaan meminjam uang untuk membantu meningkatkan tingkat pengembalian yang diperoleh dari investasi modalnya. Jika perusahaan mendapatkan pengembalian yang lebih tinggi dari biaya peminjaman dana maka leverage permodalan dapat dipertimbangkan, jika sebaliknya maka perusahaan lebih baik tidak meminjam dana (Adelegan, O 2000)

Ukuran perusahaan menjelaskan tentang keadaan atau kondisi yang terjadi pada suatu perusahaan. Terdapat beberapa proksi yang dapat digunakan untuk menentukan ukuran perusahaan yaitu jumlah karyawan, jumlah pendapatan, total aset, total ekuitas, dan kapitalisasi pasar. Jika suatu perusahaan yang besar dan mapan akan lebih mudah untuk dapat mengakses ke pasar modal. Apabila suatu perusahaan telah mencapai tingkat pertumbuhan sedemikian, maka perusahaan berkesempatan untuk membayar dividen kepada para pemegang saham dengan dana yang berasal dari pasar modal atau sumber dana eksteren dimana kebutuhan atas dana dapat terpenuhi.(Pruitt, S. W., \& Gitman, L. W. ,1991)

Di dalam prakteknya pada pasar modal, Earning Per Share merupakan alat ukur yang digunakan untuk mengukur pengakuan pasar terhadap kondisi perusahaan untuk mengetahui jumlah laba per saham. Pemberian keuntungan pada setiap perusahaan menjadi cara untuk meningkatkan investor, karena dari keuntungan itulah investor merasa tertarik berinvestasi pada perusahaan tersebut. Earning Per Share yang tinggi mencerminkan bahwa perusahaan berhasil mengelola keuangannya, sehingga dapat membagikan laba dalam bentuk dividen dan meningkatkan minat para pemegang saham untuk berinvestasi (Juhmani, A 2011)

Pembagian dividen merupakan permasalahan yang rumit dalam perusahaan dikarenakan terjadinya perbedaan kepentingan antara pemegang saham dan manajemen perusahaan yang sering disebut dengan masalah keagenan. Pemegang saham menginginkan agar dividen dibayarkan sebesar-besarnya sedangkan pihak manajemen perusahaan menginginkan laba 
perusahaan ditahan guna melakukan investasi kembali(Al-Malkawi, HN 2007). Mengatasi permasalahan tersebut maka pihak manajemen perlu untuk melakukan pengawasan dan mensejajarkan kepentingan pihak manajemen dengan pihak pemegang saham salah satunya dengan cara pembagian dividen kas yaitu pembagian laba dalam bentuk uang tunai (dividend cash). Pembagian dividen yang meningkat tiap periodenya akan susah dicapai oleh perusahaan dikarenakan keuntungan yang didapatkan perusahaan tidak selalu mengalami peningkatan melainkan adanya fluktuasi.(Ross, SA,2009)

Penelitian yang dilakukanolehAno, dkk. (2014)menyatakan bahwa profitabilitas berpengaruh signifikan terhadap dividend payout ratio. Menurut Sari dan Sudjarni (2015) kebijakan dividen tidak dapat dipisahkan karena pembagian dividen sangat berpengaruh terhadap perolehan laba pada perusahaan. Pembagiaan dividen bersumber dari laba yang didapatkan perusahaan setelah memenuhi kewajibannya baik berupa bunga maupun pajak. Semakin tinggi laba bersih yang didapatkan perusahaan maka semakin besar pula jumlah dividen yang akan dibayarkan. Oleh sebab itu profitabilitas menjadi pertimbangan penting bagi investor dalam keputusan investasi.(Hikmah, 2013)

Leverage merupakan suatu kemampuaan untuk memenuhi kewajiban finansialnya baik jangka pendek maupun jangka panjang. Semakin tinggi rasio leverage menunjukkan bahwa semakin besar kewajiban yang harus dipenuhi, sebaliknya semakin rendah rasio leverage menunjukkan bahwa mampu memenuhi pendanaan Dalam penelitian Rahayuningtyas, dkk. (2014)menyatakan bahwa leverage (DER) tidak berpengaruh signifikan terhadap dividend payout ratio.

Ukuran perusahaan yaitu perusahaan besar yang sudah mapan dan memiliki akses yang mudah untuk menuju pasar modal, dan perusahaan yang baru yang masih kecil akan mengalami banyak kesulitan untuk memiliki akses ke pasar modal. Karena kemudahaan akses ke pasar modal cukup berarti untuk fleksibilitas dan kemampuannya untuk dapat memperoleh dana yang lebih besar, sehingga perusahaan mampu memiliki rasio pembayaran dividen yang lebih tinggi daripada perusahaan kecil.

Earning Per Share (EPS) adalah rasio yang digunakan untuk mengukur besarnya pendapatan saham yang diperoleh perusahaan dari setiap lembar yang dimiliki. Earning Per Share adalah rasio yang menunjukkan berapa besar laba yang diperoleh investor atau pemegang saham per lembar saham,Abdullah dan Agaki (2014). Dalam penelitian Sarmento dan Dana (2016)menyatakan bahwa Earning Per Share tidak berpengaruh signifikan terhadap kebijakan dividend. 


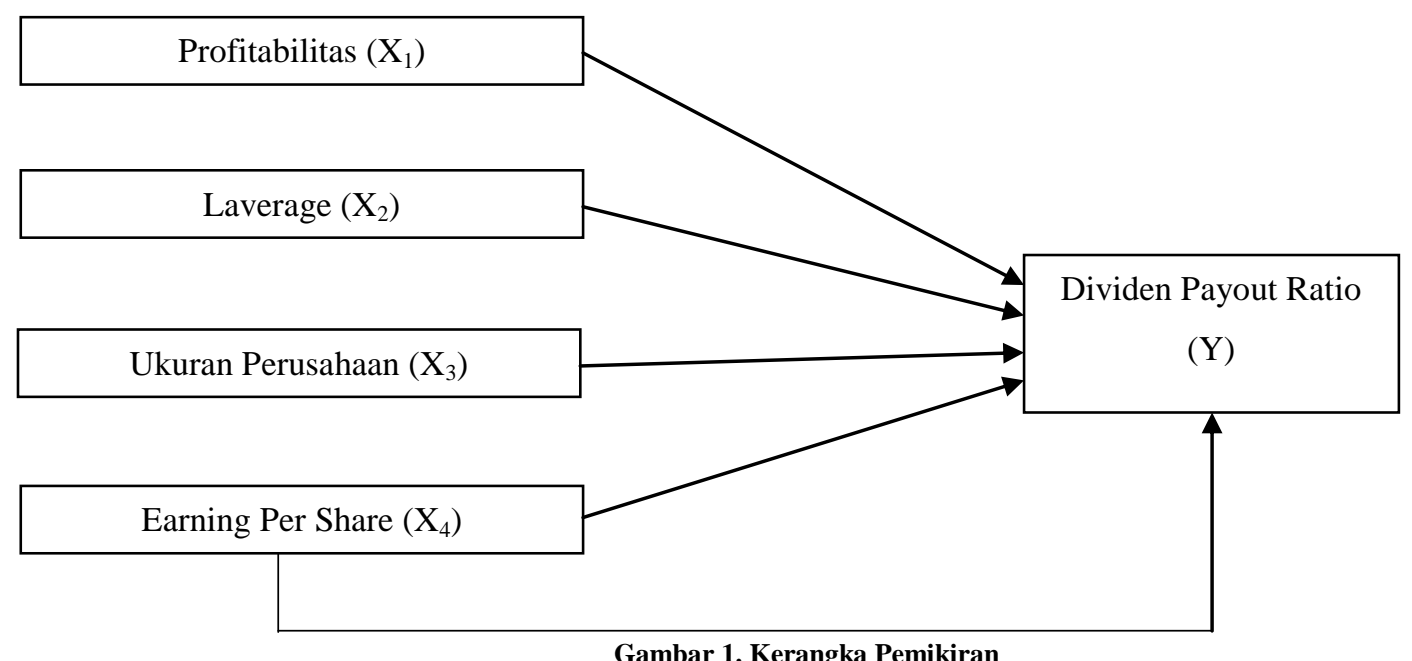

Hipotesis

Gambar 1. Kerangka Pemikiran

1. $\mathrm{H}_{\mathrm{o}}$ : Profitabilitas (ROA) tidak dapat berpengaruh signifikan terhadap Dividend Payout Ratio.

$\mathrm{H}_{1}$ : Profitabilitas (ROA) berpengaruh signifikan terhadap Dividend Payout Ratio.

2. $\mathrm{H}_{\mathrm{o}}$ : Leverage (DER) tidak dapat berpengaruh signifikan terhadap Dividend Payout Ratio.

$\mathrm{H}_{2}$ : Leverage (DER) berpengaruh terhadap Dividend Payout Ratio.

3. $\mathrm{H}_{\mathrm{o}}$ : Ukuran Perusahaan tidak dapat berpengaruh signifikan terhadap Dividend Payout Ratio.

$\mathrm{H}_{3}$ : Ukuran Perusahaan berpengaruh signifikan terhadap Dividend Payout Ratio.

4. $\mathrm{H}_{\mathrm{o}}$ :Earning Per Share tidak dapat berpengaruh signifikan terhadap Dividend Payout Ratio.

$\mathrm{H}_{4}$ : Earning Per Share berpengaruh signifikan terhadap Dividend Payout Ratio.

\section{METODOLOGI}

Jenis penelitian ini menggunakan

pada filsafat positivisme dan digunakan penelitian kuantitatif, karenaberdasarkan untuk meneliti populasi atau sampel.

\section{Tabel 1. Definisi Operasional Variabel}

\begin{tabular}{|c|c|c|c|}
\hline Variabel & KonsepVariabel & Indikator & Skala \\
\hline DPR & $\begin{array}{l}\text { Presentase dari laba yang akan dibagikan } \\
\text { sebagai dividen disebut }\end{array}$ & $D P R=\frac{\text { Devidendpershare }}{\text { Earningpershare }}$ & Rasio \\
\hline $\begin{array}{l}\text { Profitabilitas } \\
\text { (ROA) }\end{array}$ & $\begin{array}{l}\text { Rasio yang menunjukkan kemampuan } \\
\text { perusahaan untuk menghasilkan } \\
\text { keuntungan pada tingkat penjualan, asset } \\
\text { dan modal saham tertentu. }\end{array}$ & $R O A=\frac{\text { Lababersih }}{\text { Totalasset }}$ & Rasio \\
\hline $\begin{array}{l}\text { Leverage } \\
\text { (DER) }\end{array}$ & 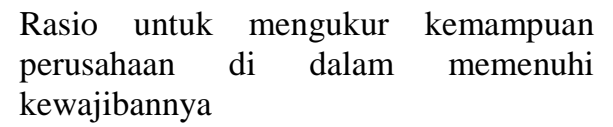 & $D E R=\frac{\text { Totalhutang }}{\text { Totalequity }}$ & Rasio \\
\hline $\begin{array}{l}\text { Firm Size } \\
\text { (FS) }\end{array}$ & $\begin{array}{l}\text { Ukuran perusahaan dalam penelitian } \\
\text { diukur dengan Log total aset. }\end{array}$ & FS $=$ Ln (Total Asset $)$ & Nominal \\
\hline $\begin{array}{l}\text { Earning Per } \\
\text { Share }(E P S)\end{array}$ & $\begin{array}{l}\text { Rasio yang menunjukkan berapa besar } \\
\text { laba yang diperoleh investor }\end{array}$ & $E P S=\frac{\text { Lababersih }}{\text { Jumlahsahamberedar }}$ & Rasio \\
\hline Populasi & merupakan & tank & penelit \\
\hline
\end{tabular}


dalam penelitian ini adalah perusahaan Manufaktur yang terdaftar di Bursa Efek Indonesia (BEI).

Penentuan sampel pada penelitian digunakan metode puposive sampling,metodepenentuan purposive sampling dengan pertimbangan tertentu dengan mengacu pada laporan keuangan perusahaan LQ45 yang ada di www.idx.co.id. Sampel penelitian ini ditentukan berdasarkan kriteria-kriteria dibawah ini:

Tabel 2. Daftar Hasil Pemilihan Sampel

\begin{tabular}{|c|c|c|}
\hline No & KriteriaSampel & Jumlah \\
\hline 1. & $\begin{array}{l}\text { Perusahaan yang terdaftardalamindeks } \text { LQ45 } \\
\text { tahun 2012-2016 }\end{array}$ & 45 \\
\hline 2 & $\begin{array}{l}\text { Perusahaan yang berturut-turut selama } 5 \text { tahun } \\
\text { masuk dalam LQ45 }\end{array}$ & (24) \\
\hline 3. & $\begin{array}{l}\text { Perusahaan } \\
\text { tidakmembagikandividenselamaperiodepenelitian } \\
2012-2016 \text { secaraberturut-turut }\end{array}$ & (5) \\
\hline 4. & $\begin{array}{l}\text { TidakMemilikikelengkapan data sesuai variabel } \\
\text { yang dibutuhkandalampenelitianini. }\end{array}$ & (5) \\
\hline To & yang masukdalam kriteria & 11 \\
\hline
\end{tabular}

Berdasarkan masalah, tujuan serta hipotesis yang telah dikemukakan diatas, maka metode yang akan digunakan dalam penelitian adalah metode kuantitatif. Untuk mendapatkan hasil penelitian yang sesuai dengan tujuan penelitian maka perlu dilakukan teknik analisis data. Menurut Sriyana (2014) regresi data panel yaitu regresi dengan menggabungkan sekaligus data cross-section dan time-series dalam sebuah persamaan. Sebelum dilakukanan alisis maka data yang ada dilakukan uji klasik dulu, setelah semua data memenuhi uji klasik maka dilanjutkan dengan uji

$$
Y_{i t}=\beta_{0 i t}+\sum_{k=1}^{n} \beta_{k} X_{k i t}+\varepsilon_{i t}
$$

Adapun persamaan model regresi panel dalam penelitian ini sebagai berikut :

atau

$$
Y_{i t}=\beta_{0}+\beta_{1} X_{1 i t}+\beta_{2} X_{2 i t}+\beta_{3} X_{3 i t}+\beta_{4} X_{4 i t}+\varepsilon_{i t}
$$

$$
D P R_{i t}=\beta_{0}+\beta_{1} R O A+\beta_{2} D E R_{i t}+\beta_{3} F S_{i t}+\beta_{4} E P S_{i t}+\varepsilon_{i t}
$$




\section{HASIL DAN PEMBAHASAN}

AnalisisDeskriptif

Tabel 3.AnalisisDeskriptif

\begin{tabular}{llllll}
\hline & DPR & ROA & DER & SIZE & EPS \\
\hline Mean & 0.502364 & 0.173636 & 0.737636 & 18.10145 & 897.5487 \\
Median & 0.410000 & 0.110000 & 0.640000 & 17.17000 & 701.0000 \\
Maximum & $\mathbf{1 . 3 4 0 0 0 0}$ & $\mathbf{0 . 8 8 0 0 0 0}$ & $\mathbf{2 . 5 5 0 0 0 0}$ & $\mathbf{3 0 . 3 5 0 0 0}$ & $\mathbf{3 4 7 0 . 0 0 0}$ \\
Minimum & $\mathbf{0 . 0 1 0 0 0 0}$ & $\mathbf{0 . 0 2 0 0 0 0}$ & $\mathbf{0 . 0 9 0 0 0 0}$ & $\mathbf{1 2 . 1 1 0 0 0}$ & $\mathbf{1 . 1 4 0 0 0 0}$ \\
Std. Dev. & 0.374190 & 0.176072 & 0.576888 & 4.613144 & 822.3965 \\
Skewness & 0.745086 & 2.091233 & 1.323925 & 1.456490 & 1.362570 \\
Kurtosis & 2.550055 & 7.347670 & 4.571080 & 4.640168 & 4.550617 \\
& & & & & \\
Jarque-Bera & 5.552849 & 83.40578 & 21.72363 & 25.61076 & 22.52892 \\
Probability & 0.062261 & 0.000000 & 0.000019 & 0.000003 & 0.000013 \\
& & & & & \\
Sum & 27.63000 & 9.550000 & 40.57000 & 995.5800 & 49365.18 \\
Sum Sq. Dev. & 7.560993 & 1.674073 & 17.97119 & 1149.179 & 36522142 \\
Observations & 55 & & & & 5 \\
\hline
\end{tabular}

\section{Uji Pemilihan Model Regresi Data Panel (Model Terbaik)}

Tabel 4.HasilUjiChow

\begin{tabular}{llll}
\hline Effects Test & Statistic & d.f. & Prob. \\
\hline Cross-section F & 6.135200 & $(10,40)$ & 0.0000 \\
Cross-section Chi-square & 51.134607 & 10 & 0.0000 \\
\hline Sumber- Data diolah Eviews 9 & &
\end{tabular}

Tabel 5. Hasil Uji LM Test

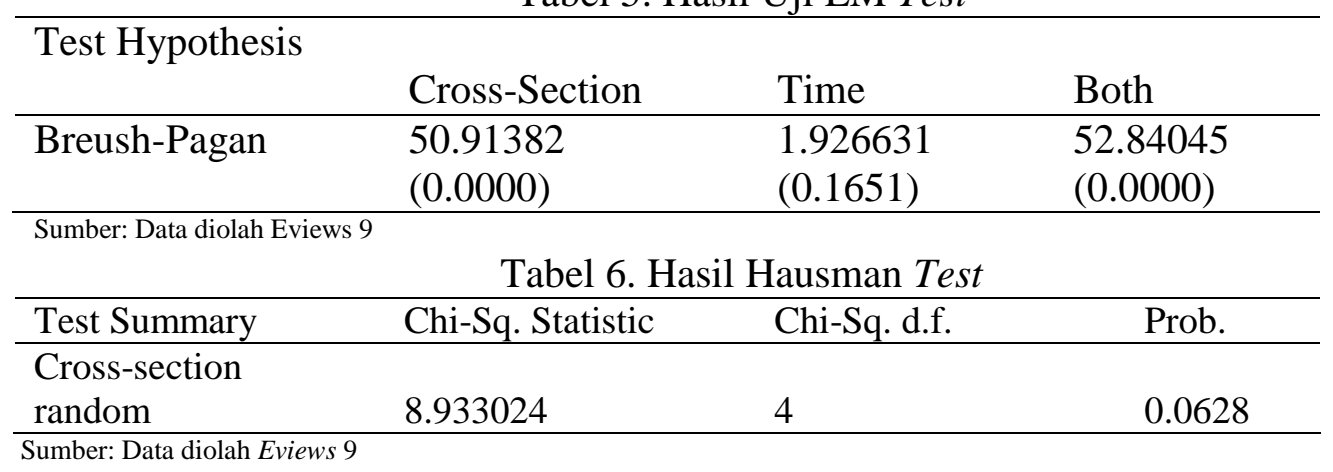




\section{Uji Asumsi Klasik}

Tabel 4.6Hasil Uji Normalitas
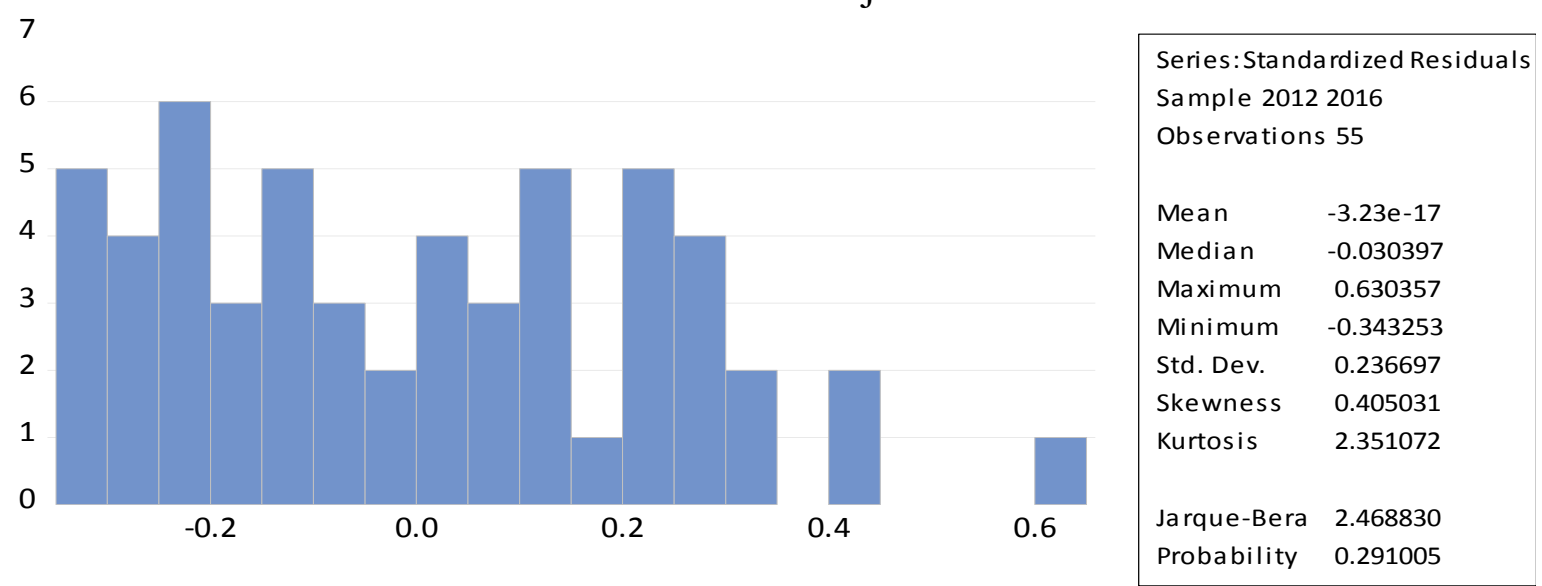

Sumber: Data diolah Eviews 9

Tabel 7.Hasil Uji Multikolinieritas

\begin{tabular}{llll}
\hline & Coefficient & Uncentered & Centered \\
\hline Variable & Variance & VIF & VIF \\
C & 0.025742 & 27.88879 & NA \\
ROA & 0.042096 & 2.763124 & 1.388131 \\
DER & 0.003562 & 3.360524 & 1.260883 \\
SIZE & $6.49 E-05$ & 24.49168 & 1.468149 \\
EPS & $1.44 \mathrm{E}-09$ & 2.287589 & 1.033604 \\
\hline
\end{tabular}

Sumber: Data diolah Eviews 9

Tabel 8.Hasil Uji Autokorelasi

\begin{tabular}{llll}
\hline F-statistic & 1.775204 & Prob. F(2,48) & 0.1804 \\
\hline Obs*R-squared & 3.787991 & Prob. Chi-Square(2) & 0.1505 \\
\hline Sumber: Data diolah Eviews & &
\end{tabular}

Tabel 9. Hasil Uji Heterokedasitas

\begin{tabular}{llll}
\hline F-statistic & 1.076844 & Prob. F(4,50) & 0.3779 \\
\hline $\begin{array}{l}\text { Obs*R-squared } \\
\text { Scaled explained }\end{array}$ & 4.362313 & Prob. Chi-Square(4) & 0.3592 \\
SS & 2.946191 & Prob. Chi-Square(4) & 0.5669 \\
\hline Sumber: Data diolah Eviews9 & &
\end{tabular}

\section{Pengujian Hipotesis}

Tabel 10. Uji T

\begin{tabular}{lllll}
\hline Variable & Coefficient & Std. Error & t-Statistic & Prob. \\
\hline C & -0.186572 & 0.219709 & -0.849179 & 0.3998 \\
ROA & 0.770750 & 0.250393 & 3.078160 & 0.0034 \\
DER & 0.149794 & 0.079483 & 1.884591 & 0.0653 \\
SIZE & 0.023262 & 0.010529 & 2.209367 & 0.0318 \\
EPS & $2.62 E-05$ & $5.17 \mathrm{E}-05$ & 0.506669 & 0.6146 \\
\hline
\end{tabular}

Sumber: Data diolah Eviews 9 
Tabel 11. Hasil Uji F

\begin{tabular}{llll}
\hline R-squared & 0.351842 & Mean dependent var & 0.191205 \\
\hline Adjusted R-squared & 0.299990 & S.D. dependent var & 0.198262 \\
S.E. of regression & 0.165879 & Sum squared resid & 1.375788 \\
F-statistic & 6.785432 & Durbin-Watson stat & 1.937070 \\
Prob(F-statistic) & 0.000192 & & \\
\hline
\end{tabular}

Sumber: Data diolah Eviews 9

Tabel 12. Hasil Uji Koefisien Determinasi

\begin{tabular}{llll}
\hline R-squared & 0.351842 & Mean dependent var & 0.191205 \\
\hline Adjusted R-squared & 0.299990 & S.D. dependent var & 0.198262 \\
S.E. of regression & 0.165879 & Sum squared resid & 1.375788 \\
F-statistic & 6.785432 & Durbin-Watson stat & 1.937070 \\
Prob(F-statistic) & 0.000192 & & \\
\hline
\end{tabular}

Sumber: Data diolah Eviews 9

HASIL DAN PEMBAHASAN

Profitabilitas Terhadap Dividend Payout Ratio

Dari hasil pengujian hipotesis, dapat dilihat pada Tabel 4.8 bahwa variabel Return On Asset(ROA) memiliki nilai koefisien regresi sebesar 0,770750 dan nilai signifikan sebesar $0,0345<0,005$. Ini menunjukan bahwa variabel Return On Asset(ROA) memiliki pengaruh signifikan dan positif terhadap Dividend Payout Ratio(DPR), ini berartisemakin tinggi ROA menunjukkan bahwa kemampuan memperoleh laba bersih oleh perusahaan semakin tinggi.

Hasil ini didukung oleh penelitian Ano, dkk. (2014), yang mengatakan bahwa Return On Asset (ROA) berpengaruh signifikan dan positif terhadap Dividend Payout Ratio(DPR). Ini menunjukkan setiap perubahan dari Return On Asset(ROA) akan berdampak terhadap pembayaran dividen suatu perusahaan. Jika ada sebuah perusahaan naik, otomatis pembayaran dividen yang diberikan kepada para pemegang saham juga naik, dan apabila laba perusahaan turun, maka rasio pembayaran dividen kepada para pemegang saham turun(Ahmed, H., \& Javid, A., 2009). Dengan laba bersih yang semakin tinggi kesempatan bagi investor untuk memperoleh dividen akan semakin tinggi, dan sebaliknya.(Arifin, 2015)

Hasil ini didukung dengan penelitian Suci (2016) yang menyatakan bahwa Return On Asset (ROA) tidak berpengaruh signifikan dan positif terhadap Dividend Payout Ratio(DPR). Ini menunjukkan bahwa perusahaan tidak akan membayar dividen yang tinggi demi untuk menjaga reputasi perusahannya tetap baik jika profitabilitas perusahaan mengalami penurunan atau berada di tingkat yang rendah.

\section{Leverage Terhadap Dividend Payout Ratio} Dari hasil pengujian hipotesis, dapat dilihat pada tabel 4.8 bahwa variabel Debt to Equity Ratio (DER) memiliki nilai koefisien regresi sebesar 0,149794 dan nilai signifikan sebesar $0,0653>0,005$. Ini menunjukan bahwa variabel Debt to Equity Ratio (DER) tidak memiliki pengaruh signifikan dan positif terhadap Dividend Payout Ratio(DPR).

Hasil ini didukung oleh penelitian Rahayuningtyas. (2014), yang mengatakan bahwa Debt to Equity Ratio (DER) tidak berpengaruh signifikan dan positif terhadap Dividend Payout Ratio(DPR).Ini menunjukkan hutang yang cenderung tinggi menyebabkan tingginya beban bunga yang harus ditanggung perusahaan sehingga 
dapat mengurangi kemampuan memperoleh laba bersih yang optimal yang berdampak pada pembayaran dividen yang lebih kecil kepada investor(Kardianah, 2013).Hasil ini didukung oleh Ulfa (2016) yang menyatakan bahwa Debt to Equity Ratio (DER) berpengaruh signifikan terhadap Dividend Payout Ratio(DPR). Hal ini menunjukkan bahwa kemampuan perusahaan dalam memenuhi semua kewajibannya adalah dengan memanfaatkan beberapa bagian modal sendiri untuk membayar hutang.Besaranutang yang dilakukanolehperusahaanharusdisesuaikand engankemampuanperusahaanbilatidakmaka hutangtidakmembuatstrukturmodal menjadioptmaltapijustruakanmenjadibeban bagiperusahaan (Patra,2012)

\section{Ukuran Perusahaan Terhadap Dividend Payout Ratio}

Dari hasil pengujian hipotesis, dapat dilihat pada Tabel 4.8 bahwa variabel Ukuran Perusahaan (SIZE) memiliki nilai koefisien regresi sebesar 0,023262 dan nilai signifikan sebesar $0,0318<0,005$. Ini menunjukan bahwa variabel Ukuran Perusahaan (SIZE) memiliki pengaruh signifikan dan positif terhadap Dividend Payout Ratio(DPR). Hasil ini didukung oleh penelitian Nurhayati (2013), yang mengatakan bahwa Ukuran Perusahaan (Size) berpengaruh signifikan dan positif terhadap Dividend Payout Ratio (DPR). Ini berarti semakin besar ukuran suatu perusahaan, maka akan semakin menurun dividen yang dibagikan (Redding, L.S., 1997). Perusahaan mampu membayar dividen lebih tinggi pada ukuran perusahaan yang besar dengan hasil omset semakin tinggi dibandingkan perusahaan yang memiliki ukuran perusahaan yang kecil (Kouki, M , 2009) Semakin besar ukuran perusahaan maka semakin besar asset yang digunakan untuk memproduksi
(Amidu,2006), bila dengan asset yang besar dan pengelolaan yang optimum akan menghasilkan keuntungan yang besar pula dan ini akan menguntungkan bagi investor (Mehta, 2012)

\section{Earning Per Share Terhadap Dividend Payout Ratio}

Dari hasil pengujian hipotesis, dapat dilihat pada Tabel 4.8 bahwa variabel Earning Per Share (EPS) memiliki nilai koefisien regresi sebesar 2,62E-05 dan nilai signifikan sebesar $0,6146>0,005$. Ini menunjukan bahwa variabel Earning Per Share (EPS) tidak memiliki pengaruh signifikan dan positif terhadap Dividend Payout Ratio (DPR). Hasil ini didukung oleh penelitian Sarmento, (2016), yang mengatakan bahwa Earning Per Share (EPS) tidak berpengaruh signifikan dan positif terhadap Dividend Payout Ratio(DPR).Karena Earning Per Share (EPS) yaitu rasio pasar yang menunjukkan besarnya pendapatan saham yang diperoleh dari penjualan setiap lembar saham.Semakin besar nilai EPS ini maka secara automatis akan memberikan dampak yang signifikan terhadap dividend payout ratio

\section{KESIMPULAN DAN SARAN}

Berdasarkan hasil pengujian dalam penelitian ini dengan bantuan program (Eviews 9), maka penelitian dapat disimpulkan sebagai berikut :

1. Profitabilitas memiliki pengaruh signifikan dan positif terhadap Dividend Payout Ratio(DPR).

2. Leverage tidak berpengaruh signifikan terhadap Dividend Payout Ratio(DPR).

3. Ukuran Perusahaanmemiliki pengaruh signifikan dan positif terhadap Dividend Payout Ratio(DPR)..

4. Earning Per Share (EPS) tidak memilikipengaruh signifikan dan positif terhadap Dividend Payout 
Ratio(DPR).Karena Earning Per Share (EPS) yaitu rasio pasar yang menunjukkan besarnya pendapatan saham yang diperoleh dari penjualan setiap lembar saham.

Bila perusahaan ingin meningkatkan nilai dividend payout ratio agar para investor menjadi senang maka manajemen harus menjaga agar ratio profitabilitasnya (ROE) mempunyai nilai yang tinggi yaitu dengan cara memaksimalkan modal yang dimiliki untuk operasional dan total assetnya tetap mempunyai nilai yang tinggi

\section{REFERENSI}

Ahmed, H., \& Javid, A. (2009). Dynamics and determinants of dividend policy in Pakistan: Evidence from Karachi stock exchange non-financial listed firms. International Research Journal of Finance andEconomics, 29, 110-125.

Amidu, M.andJ. Abor (2006).Determinants of Dividend Payout Ratios in Ghana. Journal of Risk Finance, 7 (2): 136-145.

Abdullah, Hilmi dan Ricki Fanani Agaki. (2014). Pengaruh Earning Per Share, Price Earning Ratio dan Price to Book Value Terhadap Dividen payout Ratio Pada Perusahaan Pertambangan yang Terdaftar di BEI Periode 2008-2011. Jurnal Ekonomi dan Bisnis Vol 7.

Adelegan, O (2000).he Impact Of Growth Prospect, Leverage And Firm Size On Dividend Behaviour Of Corporate Firms In Nigeria $^{\text {ee }}$, http://Www.Csae.Ox.Ac.Uk/Confere nces/2000Oia/Pdfpapers/Adelegan.Pdf

Agustina, Liya. (2016). Pengaruh Kinerja Keuangan, Ukuran Perusahaan, dan Pertumbuhan Perusahaan Terhadap Kebijakan Dividen. Jurnal Ilmu dan Riset Akuntansi Vol 5.
Ahmed, Murtaza.(2015).Critical Analysis of the Factor Afftecting the Dividend Payout:Eviidence from Pakistan. Internasional Journal of Economics, Finance and Management Sciences Vol 3.

Ano, Rizky Rurniawan, dkk. (2014). Pengaruh Likuiditas dan Profitabilitas Terhadap Dividend Payout Ratio Pada Subsektor Perbankan yang Terdaftar Di Bursa Efek Indonesia Periode 2009-2013. Jurnal EMBA Vol 2.

Al-Malkawi, HN (2007). „Determinants of corporate dividend policy in Jordan: an application of the Tobit model ${ }^{\text {ee }}$, Journal of Economic \& Administrative Sciences, Vol. 23, No.2, December pp.44-70

Arifin, Samsul. 2015. Pengaruh Profitabilitas, Likuiditas, Growth Potential, dan Kepemilikan Manajerial Terhadap Kebijakan Dividen. Jurnal Ilmu dan Riset Akuntansi Vol 4.

Baltagi, B. H. (2005). Econometric analysis of panel data econometric analysis of panel data (3rd ed.). Wiley.

Duha, AK (2009). Determinants of the Dividend Policy in Emerging Stock Exchanges: The Case of GCC Countries, Global Economy \& Finance Journal, Vol. 2, No. 2, September, pp. 38-63

Eriotis, N (2005), „The Effect of Distribution Earnings and Size of the Firm to its Dividend Policy"International \& EconomicsJournal

Hikmah, Khoirul dan Ririn Astuti. (2013). Growth Sales, Investment, Liquidity, Profitability, dan Size of Firm terhadap Kebijakan Dividend Payout Ratio Pada Perusahaan Manufaktur yang Terdaftar di Bursa Efek 
Indonesia. Jurnal Manajemen dan Akuntansi Vol 2.

Husnan dan Pudjiastuti. (2006). DasarDasar Manajemen Keuangan. Yogyakarta: UPP STIM YKPN.

Juhmani, A (2011). „Study on Leading Determinants of Dividend Policy In Malaysia ListedCompanies for FoodIndustry Under Consumer Product Sector", Proceeding of the $2^{\text {nd }}$ International Conference on Business And Economic Research, 12-16March.

Kardianah, Anwar.(2013). Pengaruh Kepemilikan Institusional, Kebijakan Utang, Ukuran Perusahaan, Profitabilitas, dan Likuiditas Terhadap Kebijakan Dividen. JUrnal Ilmu dan Riset Manajemen Vol 2.

Kouki, M.and M. Guizani.(2009). Ownership Structure and Dividend Policy Evidence from the Tunisian Stock Market. European Journal of Scientific Research, 25 (1): 42-53.

Kania, SL and Bacon, FW (2005). „What factors motivate the corporate dividend decision? American Society of Business and Behavioral Sciences E-Journal, Vol. 1, No.

Mehta, Anupum (2016). An Empirical Analysis of Determinants of Dividend Policy-Evidence from The Ue Companies, Global Review of Accounting and Finance, Vol 3, No $1,18-31$

Nurhayati, Mafizatun. (2013). Profitabilitas, Likuiditas dan Ukuran Perusahaan Pengaruhnya Terhadap Kebijakan Dividen dan Nilai Perusahaan Sektor Non Jasa. JUrnal Keuangan dan Bisnis Vol 5.

Okpara, G. C. (2010). A diagnosis of the determinant of dividend pay-out policy in Nigeria: A factor analytical approach. American Journal of Scientific Research, 8, 57-67.
Pruitt, S. W., \& Gitman, L. W. (1991). The interactions between the investment, financing, and dividend decisions of major US firms. Financial Review, 26(33), 409-430. http://dx.doi.org/10.1111/j.15406288.1991.tb00388.x

Patra, T., S. PoshakwaleandK.O. Yong, (2012).Determinants of Corporate Dividend Policy inGreece. Applied Financial Economics, 22 (13): 1079. 1087

Ross, SA, Westerfield, RW and Jaffe, JF (2009).Corporate Finance Fundamentals,Eight edition McGraw Hill

Rahayuningtyas, Septi, dkk. (2014). Pengaruh Rasio-Rasio Keuangan Terhadap Dividen Payout Ratio (DPR) (Studi Pada Perusahaan yang Listing di BEI Tahun 2009-2011). Junal Adminitrasi Bisnis (JAB) Vol 7.

Redding, L.S., (1997). Firm Size and Dividend Payouts. Journal of Financial Intermediation, 6 (3): 224248.

Parua, A., \& Gupta, A. (2009). Dividend history and determinants in selected Indian companies. Australasian Accounting Business and Finance Journal, 3(4), 45-86

Sari, Komang Ayu Novita dan Luh Komang Sudjarni. (2015). Pengaruh Likuiditas, Leverage, Pertumbuhan Perusahaan, dan Profitabilitas Terhadap Kebijakan Dividen Pada Perusahaan Manufaktur di BEI. EJurnal Manajemen Unud Vol 4 (3346-3374).

Sarmento, Jelmio Da Costa dan Made Dana. (2016). Pengaruh Return On Equity, Current Ratio, dan Earning Per Share Terhadap Kebijakan Dividen Pada perusahaan Keuangan. E- 
Jurnal Manajemen Unud Vol 5 (4224-4252).

Sriyono, Sriyono dan Rukhul Abadi. (2017). Implikasi Kepemilikan Manajerial, ROE, DER dan Nilai Tukar Terhadap Kebijakan Deviden Serta Dampaknya pada Price to Book Value, Prosiding Seminar Nasional Riset Manajemen \& Bisnis 2017, UMS

Sriyana, Jaka (2014). Metode Rgresi Data Panel (Dilengkapi Analisa Kinerja Bank Syariah di Indonesia) Yogyakarta:EKONISIA

Suci, Rizky Indra Wulan. (2016). Pengaruh Arus Kas Bebas, Kebijakan Pendanaan, Profitabilitas, Collateral Assets Terhadap Kebijakan Dividen. Jurnal Ilmu dan Riset Akuntansi Vol 5.
Sugiyono. (2011). Metode Penelitian Kuantitatif , Kualitatif $R \& D$. Bandung: Alfabeta.

Sumanti, Jorenza Chiquita dan Marjam Mangantar.( 2015). Analisis Kepemilikan Manajerial, Kebijakan Hutang dan Profitabilitas Terhadap Kebijakan Dividen Dan Nilai Perusahaan Manufaktur yang Terdaftar di BEI. Jurnal EMBA Vol 3.

Ulfa, Luluk Mariyah. (2016). Pengaruh Kinerja Keuangan, Assets Growth dan Firm Size Terhadap Dividen Payout Ratio. JUrnal Ilmu dan Riset Manajemen Vol 5.

Wooldridge, J. (2002). Econometric analysis of cross section and panel data. Massachusetts London: The MIT Press Cambridge. 